\title{
Girls' Education as a Unifying Discourse
}

In 2012, Malala Yousafzai, a Pakistani girl then fifteen years old, was shot in the head by a member of Tehrik-e-Taliban (Pakistan), a tribal-political group. Malala's father, Ziauddin, owned and operated a school, where she was also a student. The rise in recent years of a particular segment of Taliban leaders in Swat had made it difficult for him to keep the school running. In order to save their livelihood as well as afford children the chance to attend school, the father and daughter had started speaking up against the mounting extremism in their region. Malala had been writing a blog for BBC Urdu under a pseudonym since 2009, and had participated in two videos produced by the New York Times documenting the difficulties of living under the Taliban regime. The father's and daughter's actions were interpreted as besmirching the name of the Taliban and a few members of the group took it upon themselves to silence her.

Although Malala recovered shortly after the shooting, the news of this incident has since received significant attention. Educational development and aid organizations, heads of nation-states, and nongovernmental groups have rallied around Malala to express support not only for her but also for the education of girls more broadly in Pakistan and beyond. Malala was offered an opportunity to meet with Ban Ki Moon, the then United Nations secretary general, and address the United Nations general assembly; she met with President Obama to highlight the importance of education for girls; Gordon Brown, the former prime minister of the United Kingdom and later the United Nations Special Envoy for Global Education, issued a petition entitled "I am Malala" to promote universal access to primary schooling for girls. Malala secured a book contract for her coauthored autobiography, I Am Malala (2013), a children's version of which was published in 
2014, and a film in 2015. In October 2014, she was awarded the Nobel Peace Prize for her efforts for girls' education. In October 2017, she published an illustrated book, Malala's Magic Pencil.

Elsewhere, in April 2014, a militant organization that called itself Boko Haram kidnapped approximately three hundred girls from a boarding school in Chibok, Nigeria. We learned that this fringe group was composed of Muslim men. Analysts and lay people started speculating about the origins of Boko Haram, their links to Somalia, and their intentions. Several journalists translated the organization's name to "western education is a sin." It was believed that these girls were kidnapped because they were in school, which seemed logical enough-as Malala's case had recently demonstrated, Taliban/Muslim militants / Boko Haram were against girls' education. ${ }^{1}$ Except for a couple of articles ${ }^{2}$ detailing the grievances of Boko Haram related to the legacies of British colonialism in Nigeria, the entanglement of the United States in the persistent poverty in the region, and so on, no additional details about the kidnapping or the group surfaced. In the immediate aftermath of the kidnapping, the conversations focused predominantly around whether or not military intervention by the United States would be a good strategy. However, after some time, the issue was assimilated into calls for girls' education, which became the primary framework through which it was discussed. For instance, in the opening sentences of an opinion piece published in the New York Times in May 2014, Nicolas Kristof establishes a direct link between the kidnapping of the Nigerian girls and their education, calling on audiences to assimilate this new event in previously circulating certainties about the subjugation of (Muslim) girls in places like Pakistan and Afghanistan:

When terrorists in Nigeria organized a secret attack last month, they didn't target an army barracks, a police department or a drone base. No, Boko Haram militants attacked what is even scarier to a fanatic: a girls' school. That's what extremists do. They target educated girls, their worst nightmare. That's why the Pakistani Taliban shot Malala Yousafzai in the head at age 15. That's why the Afghan Taliban throws acid on the faces of girls who dare to seek an education. Why are fanatics so terrified of girls' education? Because there's no force more powerful to transform a society. The greatest threat to extremism isn't drones firing missiles, but girls reading books. ${ }^{3}$

Besides the gross misdirection in his commentary-since Boko Haram had been known to target state and international symbols, such as attacking the United Nations headquarters in Abuja in 2011, and had been involved in several instances of killing and kidnapping boys and men ${ }^{4}$ - Kristof draws sturdy connections across distinct events from Nigeria, Pakistan, and Afghanistan, and articulates girls' education as not only the cause of violence but also the solution. Julia Gillard, former Australian prime minister, makes similar linkages: "There have been some truly shocking incidents that have caused us to have tears in our eyes and sharply intake 
our breath-what happened to Malala, what has happened with the Nigerian schoolgirls - that powerfully remind us that in some part of the world, getting an education is still a very dangerous thing for a girl. ... It's [education] being targeted because it's powerful."5

Likewise, Gordon Brown in his commentary entitled "Girl Power" for Project Syndicate begins by discussing the kidnapping of the Nigerian girls and the military support required by the Nigerian government, but quickly moves on to violence against women in countries as diverse as Pakistan, Bangladesh, Morocco, India, Ethiopia, Mozambique, and South Africa, concluding with a clarion call for girls' rights and opportunities:

The Chibok girls-kidnapped simply because they wanted an education-have become a powerful symbol of this wider struggle for girls' rights. They are not the only symbols. There are also the Indian girls who were recently raped and hanged, the Bangladeshi girls now declaring child-marriage-free zones, the Pakistani girls demanding their right to education, and the African girls-from Ethiopia and Morocco to Mozambique and South Africa-demanding an end to child trafficking and genital mutilation. All of them are now more vociferous in demanding support for a world in which patriarchs no longer determine their rights and opportunities. It is their struggle, and they are increasingly leading it. ${ }^{6}$

In the course of a few sentences, issues as complicated and contextual as rape, child marriage, kidnapping, hanging, trafficking, and genital mutilation are fused together and transformed into concerns to be addressed by the international human rights regime and its advocates, patriarchs such as, such as Gordon Brown himself. The particularized issues and victims are erased to create an abstract, homogenous collective of "girls" who are demanding their rights, specifically education.

There is a systematicity across these narratives. Radically specific forms of violence are assimilated into preestablished maps of meaning, ${ }^{7}$ where brown and black girls are articulated as perennial victims of angry black and brown men and backward cultures and traditions. Differences of race, nation, and class are omitted, and a larger-than-life figure of "the girl in crisis" is constructed. If we know one (Malala), we know them all (Nigerian girls). If we design a development intervention for one, we can apply it to all. And, what better intervention is there than formal schooling, which promises deliverance not only from ignorance but also poverty, terrorism, child marriage, and genital mutilation? Education can thus empower girls to fight their own wars by reshaping themselves, asserting their choices, and demanding their rights. A graphic featured in the 2011 Nike Foundation's Girl Effect report and later displayed at the World Bank building in Washington DC and the Department for International Development building in London illustrates this point vividly. In it, a brown or black girl in a school uniform, effecting an almost superheroic gesture, deploys her book as a shield and her pen as a weapon to single-handedly attack a dragon, named "poverty." 
Such representations of girls abound in the textual and visual archives of contemporary girls' education and empowerment campaigns: Girl Effect, Girl Up, Girl Rising, G(irls)2o Summit, Because I Am a Girl, Let Girls Learn, Girl Declaration. Education appears as the social practice that can not only save girls, but also miraculously empower them to confront historical and structural issues of gender-based violence, poverty, and terrorism. This almost messianic promise of education is accompanied with a sturdy economic rationalization that educated girls will be able to enter the labor force, pull themselves out of poverty and contribute to the national GDP. Indeed, when asked about the purpose of the Malala Fund, the then CEO, Shiza Shahid, responded: "The Malala Fund . . . believes in a world where every girl is in school, and empowered with the skills to improve her life and be a change-maker in her community." "When probed further about why the fund focuses on girls' education, she elaborated: "We believe that girls are the most powerful force of change in the world. If you can invest in a girl between the ages of 10 to 14 , before she is married and becomes pregnant, you prevent her from falling into poverty. You would also give her choice-choice over when she gets married, when she has children, and the ability to earn an income."10

What we have then is an ideal, empowered, educated girl who is capable of producing radical change at multiple levels-personal, familial, and national. This book attempts to interrogate these sedimented knowledges about "the girl" and her education by unraveling a specific modality of this figure: the Muslim woman/girl. ${ }^{11}$

\section{THE MUSLIM WOMAN/GIRL}

Contemporary campaigns about girls' education are not idealistic notions without a historical and geographical place. Edward Said notes that "every idea or system of ideas exists somewhere, it is mixed in with historical circumstances." ${ }^{12}$ Looking for the place of ideas directs attention to the "embodied locus of social experience." ${ }_{13}$ The recent global rallying around girls' education has been in relation to specific populations and nations in the global South, where it is assumed that poverty, terrorism, and gender-based violence are an effect of the lack of girls' access to schooling. Since schooling is viewed as a sign of modernity and progress, lack of access often signals a lack of awareness and a disengagement with modernity. Oftentimes, the composite figure of the Muslim woman/girl emerges as an example par excellence of this backward femininity - she is threatened by religion, tradition, patriarchy, and local customs, is ill-equipped to survive in the modern social order, and is thus unable to fulfill her potential. It is this passive feminine figure that was invoked by Laura Bush in 2001, when as first lady of the United States she cited the plight of the Afghan women as one of the rationales for American military intervention: "The fight against terrorism is also a fight for the rights and dignity of women." ${ }^{14}$ Earlier during the Gulf War, the American government and 
media made extensive use of the maltreatment of women to represent the moral, cultural, and political deficiencies of the Islamic world, warranting the 1991 operation against Iraq. ${ }^{15}$

Most recently, during his election campaign, the current U.S. president, Donald Trump, activated the trope of the oppressed Muslim woman by criticizing Ghazala Khan, the Pakistani-American mother of U.S. Army Captain Humayun Khan, who was killed in 2004 in Iraq. Khan and her husband appeared at the Democratic National Convention, during which he spoke but she was quiet. Trump remarked, "If you look at his wife, she was standing there. She had nothing to say. She probably ... maybe she wasn't allowed to have anything to say. You tell me."16 Trump pointed to prevailing knowledge about Muslim women's oppression to add fodder to his prior claims about Islam being alien to American values and his calls for banning Muslims. Khan later said that she was too emotional to speak on stage. Subsequently, President Trump issued an executive order on "Protecting the Nation from Foreign Terrorist Entry into the United States," which also invoked violence against Muslim women to garner support for greater policing and regulation of Muslims in America. ${ }^{17}$ The Executive Order commits the Trump administration to publicly make available news about the "number and types of acts of gender-based violence against women, including honor killings, in the United States by foreign nationals." It thus deploys the trope of "honor killings" to cast foreign-born immigrants-primarily from Muslim countries-as suspect.

The discursive trope of the oppressed Muslim woman/girl is quite malleable and can be grafted onto any girl from Muslim-majority countries or the Muslim diaspora. We already know Malala's story. In another instance, in 2016, Nicholas Kristof wrote an article entitled "Meet Sultana, the Taliban's Worst Fear," which tells the story of Sultana, a girl from Afghanistan who under the Taliban-dominated south struggles to acquire an education. ${ }^{18}$ Hers is an inspiring example of courage and tenacity. She figured out ways to study at home, creatively using online applications, thus defying the Taliban's injunctions. This is a story of a Muslim girl who, with the support of her family, found creative ways to subvert local configurations of patriarchy in a conflict zone. But that is not how Kristof relates the story. Instead, we learn about the efforts of an American professor, Lawrence M. Krauss, and a student, Emily Robert, who are impressed with Sultana and try to get her admitted to a community college in Iowa. In Kristof's version, it is the withdrawal from her family and country, and movement toward the 'land of the free' and a community college education that is the ultimate achievement of justice for Sultana. He, thus, calls out the U.S. administration for not awarding girls like Sultana an American visa. Earlier, he had documented the struggles of Mukhtar Mai, a Pakistani woman from Merawala who was gang-raped but triumphed against the atrocities by launching a campaign for girls' education and human rights. Her story too-in the way Kristof tells it_confirms the regressive nature of Islam, Muslims, and Pakistanis, and bolsters the human rights agenda. ${ }^{19}$ 
There is, then, a persistent and almost predictable storyline about the figure of the Muslim woman/girl. Malala, Sultana, and Mukhtar Mai simultaneously represent the oppression of Muslim women and girls and the emancipation from local cultures and traditions that is possible through education. The subject position of the "educated hence empowered girl" has been installed as the ideal toward which all Muslim girls must aspire. What we are left with, then, is a sturdy binary that pits Muslim girls against empowered girls, a binary that is invoked and solidified across multiple discursive fields from development and humanitarian campaigns to literature and news media.

I have been frustrated and challenged by what seems to be an impossible task of interrupting this storyline. Several years ago, I started examining the politics of race, gender, and religion in the deployment of the figure of the girl-in-crisis in girls' education and empowerment campaigns such as Girl Effect, \#BringBackOurGirls, and \#IamMalala. I was reminded of how this girl resembles her predecessor, the "Moslem woman" or "Musalman woman" who, too, during the eighteenth and nineteenth centuries in colonial India, emerged as a figure to be saved from backward cultural practices of purdah, seclusion, early marriage, and religious superstitions. Colonial administrators, Christian missionaries, as well as Muslim social reformers-for different reasons-claimed that education would save/civilize/ reform these women. Christian missionaries established schools for girls and initiated zenana-visitation programs. ${ }^{20}$ The colonial administration established book prizes, encouraging local authors to write books in the vernacular for girls. Muslim reformers wrote didactic texts to educate women and girls, guiding them away from "superstitious" rituals and toward the "correct" practices of Islam.

While the missionaries, colonial officers, and social reformers differed in their conceptualization of the end toward which women and girls were to be educated, as well as what constituted this education-as this book will delineate-what is critical to note is that then, too, Muslim women had emerged as an ideal site for reform. Tied to them was the survival of the future social order; they offered a guarantee for positive futurities. These frames are not much different from how girls are articulated today in the transnational development regime. The former UN secretary general Ban Ki-moon sees girls as an "untapped natural resource" and a "smart investment," ${ }^{21}$ and the UN Foundation's Girl Up campaign positions girls as "bright, talented and full of potential." ${ }^{22}$ Investment in girls' education is a key area of advocacy and one of the main issues in global agendas from the Millennium Development Goals to the Sustainable Development Goals.

So, women's and girls' education has been a pregnant discursive space, enticing a broad range of groups to advance their social projects. When ideal girlhood is defined, its "other" too is delineated. We thus find myriad articulations of failed girlhoods in the past as well as the present. This book is an effort to trace such knowledge-making practices. However, given the extensive work already underway 
on colonial narratives about Muslim women and the current western discourses on Muslim girls (including my own work), in this book I focus on debates internal to Muslim societies. I examine discourses on Muslim women's and girls' education across three moments in the history of colonial India and postcolonial Pakistan and track the production of ideal educated girlhoods. I ask: Who is this educated girl? What is she expected to know? Who is authorized to teach her? Where does she learn? Toward what ends? I track the processes, forces, logics, and impulses of educative missions to point to the diverse kinds of citizen-subjects, religious subjects, gendered subjects, and worker-subjects that they produce. Such an effort hopefully will illustrate the historical and contingent production of the ideal girlsubject, and dismantle assumptions about the uniform character of Muslim womanhood and girlhood. Furthermore, it will give the reader a sense of the internal debates and tensions around the construction of Muslim womanhood/girlhood. Centering the narratives of Muslim social reformers or focusing on Pakistan does not mean that I avoid attending to the transnational flows of ideas, capital, and peoples. These narratives, as the book will show, are in fact deeply shaped by transnational contexts.

Specifically, I examine discourses on girls' education at the turn of the twentieth century in colonial British India; the first decades after the political establishment of Pakistan; and the contemporary moment, defined as the turn of the twenty-first century in postcolonial Pakistan. I explore a broad range of texts-novels, political speeches, government documents, periodicals, advertisements, television shows, and first-person narratives-to understand the rationales given for women's and girls' education, the ideal curriculum for girls, as well as the most suitable spaces for this education. This investigation provides insights into the creation of ideal Muslim woman-/girl-subjects, who have specific relationships with themselves, the patriarchal family, Islam, the nation-state, and paid work. Viewing gender and education as discursive projects, then, opens up these categories to an analysis of relations of power, enabling me to elaborate on how the figure of the Muslim girl functioned socially and culturally. It also creates space for an examination of multiple, even contrasting, articulations of this subject. In this way, I illuminate the ways in which education, as a social project, facilitates self- and populationalgovernance, and gender emerges as a key social construction in and through which these processes unfold. In particular, the book demonstrates how visions of education for girls are variable and historically contingent. They reflect the dominant, and at times competing, conceptions of feminine subjectivity, driven by the material and cultural struggles for power. I read the discourse on girls' education as a site for the construction of not only gender but also class, religion, and nation. By examining the figure of the "educated girl" genealogically, we can understand why Muslim girls and women have occupied the roles that they have, and begin to imagine alternatives for both feminine subjectivity and educational opportunity. 


\section{The Making of Gender}

My orientation to gender is informed by feminist poststructuralist theories which decenter the humanist Cartesian subject who thinks, represents, and acts. ${ }^{23}$ Instead, feminist poststructuralist concerns direct researchers to consider the discursive practices that bring objects and subjects into being, as well as examine the historical conditions that make particular subject positions possible. ${ }^{24}$ Foucault describes discursive practices as:

not purely and simply ways of producing discourse. They are embodied in technical processes, in institutions, in patterns for general behavior, in forms for transmission and diffusion, and in pedagogical forms, which, at once, impose and maintain them.... These principles of exclusion and choice, whose presence is manifold, whose effectiveness is embodied in practices, and whose transformations are relatively autonomous, are not based on an agent of knowledge (historical or transcendental) who successively invents them or places them on an ongoing footing; rather, they designate a will to knowledge that is anonymous, polymorphous, susceptible to regular transformations, and determined by the play of identifiable dependencies. ${ }^{25}$

Examining this "will to knowledge" entails attending to the speech acts, institutional policies, and practices that produce gendered subjects and subject positions. It also includes a consideration of the circulation and exercise of power that authorizes particular representational claims as inevitable or dominant. Judith Butler explains, "gender is not always constituted coherently or consistently in different historical contexts, and because gender interacts with racial, class, ethnic, sexual and regional modalities of discursively constituted identities ... it becomes impossible to separate out 'gender' from the political and cultural intersections in which it is invariably produced and maintained." ${ }^{26}$

Thus, in this book, I explore the multiple articulations of educated girlhoods, paying attention to the dense historical networks within which they take shape. In doing so, the book enacts core feminist commitments to the fluidity of gender formation and sees gender categories as always in-the-making. ${ }^{27}$ In fact, a key move that I make is to trace the production of categories of gender. I do not take "woman" and "girl" to be self-evident. These categories are socially constructed and their content changes with time. In the archives considered for this book, in some moments the distinction between woman/girl does not hinge on age but on marital status; in other moments, it is securely centered on biological age. Yet, in other cases, the state adamantly refuses a distinction between women and girls, as was the case of the British colonial state. ${ }^{28}$ Even these distinctions are not always a given, because social class also has repercussions on who gets marked as a "woman" and who is infantilized into a "girl," and when. Indeed, the point of narration or the speaker's positionality matters too. As I will show in the book, the Pakistani state often infantilizes women through terms such as bachi (girl-child), which are used to describe even women over eighteen years old. ${ }^{29}$ In doing so, such 
women are brought securely under the control of the state and the patriarchal family. In the texts considered for this book we encounter Muslim women and girls in myriad forms: Musalman aurat, sharif bibi, sughar beti, sharif larki, parda-nasheen, teddy girls, ultramodern, buri aurat, quam ki bachi, bazari aurat, empowered girl, and student. The same female can emerge as a woman in one articulation and be marked as a girl in another. My task, then, has been to unpack these circumstances and the politics surrounding them. It is crucial to pay attention to these characteristics and dynamics when considering the making of woman/girl. Muslim womanhood/girlhood thus comes into being as an effect of identity statements, roles, and limitations that are used to describe particular bodies..$^{30}$

This does not mean that we cannot detect dominant representational frames of Muslim women and girls in the archives. Indeed, one of the key arguments that I advance in this book is that over the century, with the expansion of mass schooling, the extension of the juridical powers of the state, as well as the convergence on the figure of the girl in the international development regime, ${ }^{31}$ we observe a disaggregation of the composite figure of Muslim woman/girl that was previously dominant. South Asian historian Ruby Lal has observed that while during the early decades of the nineteenth century we can detect a female figure engaged in playful activities who can be read as a "girl," this figure morphs over the course of the century into a compound of girl-child/woman. ${ }^{32}$ Girls come to be invoked primarily as future wives and future mothers. The texts that I have surveyed in this book from the turn of the twentieth century show instances where the girl/woman is articulated outside the discursive frames of future wife and future mother as well. What we have then are the beginnings of the emergence of a "Muslim girl" and her distinction from the Muslim woman. By the turn of the twenty-first century, I argue, the Muslim girl crystalizes as a dominant figure in her own right that deserves protection, education, and advocacy. Entities as wide-ranging as representatives of nation-states, multilateral development agencies, philanthropists, human rights activists, and journalists participate in the production of this subject. As an affectively charged figure, she calls forth projects and funds to reform not only her but also her family and her community and, in doing so, legitimizes myriad state and nonstate interventions.

\section{REFORMING WOMEN AND GIRLS: THEN AND NOW}

The recent focus on gender in the field of international development emerged during the 1970 s and 1980s, when it was argued that women were marginalized in development projects. This awareness was an effect of, and grounded in, broader political and social movements, including women's and civil rights movements in the United States, anticolonial and nationalist struggles in the global South, and geopolitical contestations during the Cold War. Since then, many formal efforts to include women in the development paradigm have taken place under 
the rubrics of Women in Development, Women and Development, and Gender and Development. ${ }^{33}$ During the 1980 os and 1990s, however, a consensus arose that not only women but adolescent girls as well could participate in promoting development. Since high fertility rates were negatively correlated with national GDP, it seemed logical that focusing on girls, keeping them in schools, and delaying marriage and childbearing would be a sound policy. This consensus was institutionalized through a range of programs during the 1990s and 2000 s that focused specifically on girls. The United Nations, for instance, declared 1991-2001 as the Decade of the Girl Child; the fourth World Conference on Women held in 1995 in Beijing cited "the girl-child" as one of the twelve critical areas of concern; the World Bank founded its Adolescent Girls Initiative in 2007; the UK's Department for International Development launched Girl Hub in 2010; the United Nations marked October 11 as the Day of the Girl Child in 2011; and most recently, in 2015, the White House launched the Let Girls Learn campaign. ${ }^{34}$ These efforts have been given additional weight by transnational corporations and foundations such as Wal-Mart, Intel, Procter \& Gamble, Nike, Plan International, and NoVo Foundation, which have launched their own campaigns for girls. Journalists, too, have been at the forefront of reinscribing the convergence on the girl with documentary series such as Girl Rising (girlrising.com), and popular books, such as Half the Sky: Turning Oppression into Opportunity for Women Worldwide, written by Nicolas Kristof and Sheryl WuDunn; and I Am Malala, written by Malala Yousafzai and Christina Lamb. The broader focus on gender in development, then, has congealed around the figure of the girl as the "change agent." While other projects aimed at women's development, in particular microcredit, are still considered significant, there has been a marked policy and investment shift toward girls and their access to schooling. ${ }^{35}$

The figure of the girl, then, promises all kinds of societal rewards. ${ }^{36}$ However, differently racialized girls offer different types of rewards and are hence policed differently. Unlike their counterparts in the global North, educated girls from the global South, racialized as brown or black, promise not only social harmony but also economic growth, an end to terrorism, and population control. Black girls, for instance, are often viewed as the key to ending the epidemic of HIV/AIDS in African countries; likewise, brown, Muslim girls are popularly touted as ideal for reforming the extremist tendencies in Muslim-majority nations. As noted earlier, these promises are not a new invention; they are the current episode in a long series of productions where brown women's and girls' education is portrayed as the best way to save not only them but also their communities and nations. Indeed, in the context of colonial India, native women's emancipation through education was one of the key discursive tropes that legitimized colonial intervention, paved the way for Christian missionaries to enter the homosocial spaces of the zenana (a part of the house reserved for women), as well as provided new opportunities for Indian nationalists to regulate women's bodies and mobility. 
A range of actors, from British colonial officers, female teachers, and missionaries, to Hindu and Muslim social reformers, took up the call for Indian women's education to express their particularized views about ideal femininities and, relatedly, about ideal class relations, and religious and nationalist subjectivities. For instance, during the eighteenth and nineteenth centuries, certainty about the barbarity of Muslims was established through the framing of the Muslim woman as simultaneously victimized and capable of inciting fanaticism in men. In 1871, the bishop of Calcutta wrote that "female education is of the utmost moment in India for religious, social, and even political reasons, there being no more effectual nurses of the fanaticism of the Musalman and of the superstition of the Hindoo than the women of India." ${ }^{37}$ Likewise, references to the practices of purdah, infanticide, widow remarriage, child marriage, and polygamy abound in colonial archives. Texts written by social reformers, such as Helen Barrett Montgomery's Western Women in Eastern Lands (1910) and Annie Van Sommer and Samuel Zwemmer's Our Moslem Sisters (1907), narrate the oppression of Muslim women. Such texts incited pity from their readers (who were often Protestant Christian women) toward their "moslem sisters," and disgust toward "Moslem law" and the "Muhammadan religion." Women's magazines such as the Heathen Woman's Friend (1869), Englishwoman's Review (1886), and Women's Missionary Advocate (1880), among others, similarly conveyed Indian women's deprivation. These texts reinscribed the racial logics that undergirded colonial adventures. Native women were viewed as biologically inferior, a reasoning that worked well within the social Darwinist ideas popular in late nineteenth-century Britain. The colonial state, too, signaled its superiority in and through laws centering on the female body. These included the Sati Abolition Act (1829), the Widow Remarriage Act (1856), and the Age of Consent Act (1891), among others.

The British colonizers' interest in female education in India began with learning more about the deficits of Indians as well as providing proper education to mixed-race children of British soldiers and those Indians who were closely related to British commerce. ${ }^{38}$ Hence, much of the funding for female education was directed by a racial logic. Over time, and with the efforts of the missionaries, native women too were engaged in the educational enterprise. The Charter Act of the East India Company in 1813 provided the requisite permission for missionaries to start experimental girls' schools in North India. American missionary societies, for instance, established day schools-often called "bazaar schools." One of the ways in which girls were lured to these schools was through a daily attendance allowance, an incentive that appealed to poor Muslims and Hindus alike. This made such schools popular for poor and lower-caste girls, but unpopular for upper castes and nobility. Both Hindu and Muslim elites did not send their daughters to these schools due to the fear of Christian proselytizing as well as a desire to avoid exposure to lower classes. This prompted the missionaries as well as the colonial administration to rethink their strategies around women's education, and 
education in the zenanas emerged as a viable alternative. Per this policy, missionary women would enter the homosocial spaces of the zenana to educate native elite women, and continue to educate Christian converts in orphanages and boarding schools. Significantly, in relation to the zenana, the assumption was that in addition to direct teaching, mere contact with missionary women would reform the natives. Thus, during the latter half of the nineteenth century, missionaries lost interest in the enterprise of public girls' schooling since it did not provide access to local elites; instead, they strengthened the zenana visitation programs. Observing this trend, historian Tim Allendar notes that while educative efforts in the early nineteenth century were limited to mission schools, by the early twentieth century, female education was politicized and can be viewed as an effort by the raj to support specific forms of feminine subjectivities. ${ }^{39}$ Overall, however, there is much more discourse on female education than real funding or infrastructure. Scholars have estimated that by the end of the nineteenth century only 1 to 2 percent of school-age girls were in schools. ${ }^{40}$

The discourse on Indian women's education also created the space for the emergence of an agentic British woman. Historian Jane Haggis notes that the project of empire building offered British women several avenues to secure a public role for themselves and to assert their agency in relation to both British men and the colonized peoples. She traces the link between the struggle of British women to obtain the right to vote at home and their portrayal of themselves as resourceful, enlightened, independent agents vis-à-vis victimized Indian women..$^{41}$ Missionaries and other women who chose to travel to India to save their sisters often sought not only to convert Indian women to Christianity but also to introduce Victorian middle-class social mores, aimed at transforming native women into good wives and mothers. ${ }^{42}$ This was in contrast to the positions that they sought for themselvespositions of active workers, hoping to leave behind their lives as domesticated wives. ${ }^{43}$ While British women were to come to the rescue of Indian women due to their shared womanhood, social class and race tempered that alliance. British ladies always appeared as "superior gendered authority, as better women." 44 Thus, these educative activities helped the colonizers establish their moral superiority in relation to the natives and deepen the reach of the colonial state.

Over time, Indian elites began to view missionary educative interventions with suspicion, particularly as elite Indian women began to convert to Christianity. The threat of conversion dampened the enthusiasm for zenana visitations. The Aligarh Institute Gazette, a journal with a predominantly Muslim elite readership, for instance, pleaded its (presumably male) readers to not allow mission ladies into their houses. ${ }^{45}$ To address this threat, as well as to reform Muslim women according to their own visions, Muslim social reformers put forth their proposals for women's education, which I will explore in detail in chapter 2. These social reformers differed in their allegiances to the British and their social class interests mediated their views on women's education. Suffice it to say that, from their 
perspective as well, women's superstitious religious practices and customs were viewed as remnants of the past that threatened the survival of the Muslim community or quam, ${ }^{46}$ and therefore they too called on women to reform their ways. Some Muslim social reformers advocated for an education that introduced women to Victorian norms of domesticity, while others set out to forge distinctly Islamic education for women. Either way, education was to signal familial respectability, engender civilization, and correct the mistakes made by Muslims in the past.

Thus, from Christian missionaries and Muslim social reformers of the past to women's rights advocates and development practitioners today, a range of different social groups have converged on the figure of the Muslim woman/girl. This figure has functioned to incite fear of societal degeneration as well as hope for the future. She is passive but embodies energy and power, which if not harnessed properly through education, can spell the destruction of society. However, when educated appropriately, she can inaugurate familial, national, and civilizational progress. Thus, the education of Muslim women and girls has been intricately linked with governing them and molding them into ideal subjects, an argument that this book explicates.

\section{Governmentality and Education}

I trace the shifting constitutions of the ideal educated female subject across three moments to illustrate how they align with ever-changing rationalities for the government of populations and individuals. Foucault advanced the concept of governmentality to explain the ways in which modern European nation-states administered and managed their populations. ${ }^{47} \mathrm{He}$ later expanded the definition to include practices that "constitute, define, organize and instrumentalize the strategies that individuals in their freedom can use in dealing with each other." ${ }^{8}$ Governmentality, then, directs us to consider the ways in which individuals take up particular knowledges, practices, and behaviors from within a field of possibilities, and willingly self-govern according to particular rationalities. The "art of governing" then entails guiding individuals toward desired practices that make them simultaneously more obedient and productive. In this way, power is exercised not only through coercion but also through engendering self-regulation and self-surveillance.

Given the didactic nature of the enterprise of education, it is not surprising that scholars have analyzed educational projects for inducing specific modalities of selfand populational governance. ${ }^{49}$ Indeed, colonial interventions did not just entail economic and political exploitation, but also cultural domination and an active erasure of local/indigenous knowledge ecologies. ${ }^{50}$ Within the European project of empire building, education was a technology of colonialist subjectification, as it represented the colonized to themselves as inferior when compared to Europeans. ${ }^{51}$ Consider Edward Said's recollection of his schooling experience: "the tremendous spiritual wound felt by many of us because of the sustained presence in our midst 
of domineering foreigners who taught us to respect distant norms and values more than our own. Our culture was felt to be of a lower grade, perhaps even congenitally inferior and something of which to be ashamed." ${ }^{2}$ Education-defined as including not only formal school curricula, pedagogies, and spatialities, but also hidden curricula and pedagogies enacted outside school contexts-then, is one of the key social practices through which dominant rules of society, as well as strategies for self-disciplining, are established and reproduced. Such practices in turn sediment particular relations of power and exploitation.

In the context of colonial India, the British viewed education as a means not only to create workers for their expanding bureaucracy but also to socialize the native elite into English tastes and ways of thinking..$^{53}$ As noted earlier, some of the earliest interventions in education can be traced to the Charter Act of 1813, which in addition to creating an opening for missionary educative enterprises, also allocated one hundred thousand rupees annually for "the revival and improvement of literature, and the encouragement of the learned natives of India." ${ }^{54}$ Over the next twenty years, there was debate around which kinds of literatures-indigenous/vernacular or western - should be circulated, until Lord Thomas Macaulay decidedly moved the debate in favor of western literature through the English Education Act in 1835. While vernacular languages continued to be studied and taught, the English language shared an equal and oftentimes greater status. Furthermore, a cursory glance at Macaulay's famous Minute on Education (1835) shows that English models of schooling were introduced to create a cadre of people who could serve as cultural intermediaries between the British and their Indian subjects as well as staff the colonial bureaucracy. In 1837, Persian was abolished as the court language and was replaced with English, and, by the 1850s, English became the primary language of business.

The British were largely interested in university education and less so in primary and secondary education, as the former helped produce the translators and clerical staff needed for municipal governments. When Urdu departments were added to institutions of higher learning, they were viewed as providing a pathway to western cultural mores for Indians. The English versus Urdu debates, according to South Asian historian Margrit Pernau, were about "whether the cultural transformation [of the natives] could be brought about effectively through English, or whether the primary objective should be 'to make the improvement and cultivation of the vernacular tongue go hand in hand with the promulgation of the thoughts and ideas, the solidity of reasoning and freedom of enquiry of the European world." 55 The establishment of Urdu departments and patronage for translations from English to Urdu fit this broader objective of transformation of Indian thought and knowledge. Over time it was determined that mass education in the vernacular, too, should be provided, although the government remained less committed to funding it. Wood's Dispatch of 1854 called for providing higher 
education in English to the elites and basic education in the vernaculars to the masses. This policy shift led to the establishment of institutions such as departments of education in each province, as well as teacher-training schools, government colleges, high schools, and middle schools.

The British had thus far let the Indians undertake the civil administration of the colony; however, much of this changed after the War of Independence of 1857 (or what the colonizers termed as the rebellion or insurrection against the East India Company). While both Muslims and Hindus revolted, it was primarily Muslims who bore the blame. ${ }^{56}$ For instance, Henry Harington Thomas, an official of the Bengal civil service, wrote in a pamphlet entitled the Late Rebellion in India and Our Future Policy (1858), "Hindoos were neither the contrivers nor the primary movers of this insurrection." 57 To halt future unrest, he went on to elaborate the role of education in producing a cadre of people that would hold favorable views of the English:

The general introduction of our own language seems, to my view, the most certain way to bring the natives nearer to the Government. Once [we] let them speak and understand English, and they will begin to think in English, and to have English aspirations. They will discover in due time, that the British Government, though vexatious, and unintelligible to common Oriental minds, is superior to the Mahomedan after all, and the rising generation might yet appreciate those advantages of our administration, to which their fathers had been obstinately blind. ${ }^{58}$

Muslims, then, emerged as one of the key target populations that had to be molded in specific ways to align with the British. If we are to understand empire as "practices of power," 59 as Partha Chatterjee argues, we can read the formal and informal educational practices of the British during the colonial period as playing an integral role in the governance of subjects. Indeed, Henry Harington Thomas proposed education in the English language and literature not only as a means of producing a subject population that was amenable to British rule but also one that appreciated British cultural superiority and, hence, would set out to reform its own barbaric ways: "Their growing familiarity with our language, and their acquirement of our literature, would render their relapse to barbarism impossible; their predilection for torture and massacre would be soon eradicated." ${ }^{\circ}$ From 1857 onward, then, the medium of higher education in India steadily became English, with a focus on European literature. The elite Muslim social classes who had access to employment and resources under the Mughal rule were slow to adapt to the new administration. Hence, civil administration gradually shifted from Muslims to Hindus. Furthermore, Krishna Kumar observes that British education policies not only established knowledges worthy of study but also transferred teachers and curriculum from community life to state control. ${ }^{61}$ Colonial institutions then became arbiters of authority and upward mobility. Access to colonial education, however, was mediated by race and 
social class. An education code introduced in 1883, for instance, "restricted nearly all secondary schooling for girls, and the funding for teacher training of women, to Eurasians and Europeans only." ${ }^{\prime 2}$ Race and social class interests continued to mediate the colonial state's ventures into education.

It is in this context that male Muslim social reformers, anxious about their own declining status and lack of access to wages and patronage, called for reorganizing their institutions of learning and set out to professionalize themselves. Women emerged as a key discursive space in and through which social reformers articulated their visions for a new social order. This included calls for improving women's religious practices, contribution to the household, and relations with men and children, all to be accomplished through proper education. In the next chapter, I will show that a diversity of views about "the woman question" circulated at the turn of the twentieth century. For now, it is crucial to recognize that in the post1857 context, with the introduction of British institutions of learning and their preference for English language and literature, different groups of Muslims set out to engage with critical questions about their own identity and futures. These questions were in turn linked with concerns about appropriate knowledges for Muslims and their modes of transmission, and Muslim women emerged as a key node in and through which these concerns were sorted out.

After the establishment of Pakistan, too, women continued to be a central discursive site through which social issues were debated. During the 1950 os and 1960s, Pakistan was embroiled in questions about national identity, economic development, and modernization, and ideas about ideal educated subjects emerged at the nexus of those concerns. As I will show, women were posited as "daughters of the nation" and/or "scientifically inclined mothers" of future generations-all in the service of the patriarchal family and the nation. Schools were viewed by some as hospitable and by others as suspect. Likewise, in Pakistan today, contestations around school curricula and the classed outcomes of schooling show how the enterprise continues to make possible some subject positions while erasing others. Significantly, with the institution of mass schooling taking central stage in the development of youth, other societal institutions such as the family and religious institutions find themselves clamoring for a role in the moral development of young people.

\section{GENEALOGY IN FEMINIST RESEARCH}

A turn toward the archive is not a turn toward the past but rather an essential way of understanding and imagining other ways to live in the present. KATE EICHHORN ${ }^{63}$

I started writing this book to denaturalize the assumptions about the figure of the Muslim girl-and relatedly, about Islam, Muslim men, Pakistan, and education's 
emancipatory promise-that have attained an almost commonsensical status in/ through international development discourses. An effective way for me to do this was to trace how education, girlhood, and womanhood are not static, rigid formations but effects of social negotiations, which necessarily means that there is an inherent diversity in what constitutes an ideal educated Muslim girl. Significantly, there could never simply be one ideal given how diverse our societies and their investments are. Hence, I decided to write a genealogy of the educated Muslim girl, focusing in particular on discourses internal to colonial India and Pakistan. In doing so, I hope to throw into question the universals produced not only by transnational development regimes but also institutions internal to Muslim societies. A genealogy further enables me to show that meanings around educated girlhood have shifted over time. Deploying these analytics then calls on us to investigate the relations of power that propped up particular visions of ideal girlhood in the past as well as in the present.

Genealogies are philosophical and historical examinations that elaborate the ways in which knowledge-making practices intersect to produce/erase subject positions. In this way, genealogies are not traditional histories or teleological narratives of progress; they do not have singular origins, but multiple beginnings and middles. They are rhizomes ${ }^{64}$ - a collection of roots that have no beginning or end per se, and which go off in different, unpredictable directions. As a genealogist, I highlight how things become, but while doing so hope to highlight the fluidity and productivity as opposed to accomplished and stable objects/subjects. The practice of genealogy, informed by poststructuralist thought, directs me to consider practices of language and circulation of power that bring particular representations into effect. I ask: "under what conditions and through what forms can an entity like the subject appear in the order of discourse; what position does it occupy; what functions does it exhibit; and what rules does it follow in each type of discourse?" 65 In other words, a genealogy calls for decentering the subject and focuses instead on the concrete practices that produce that subject. ${ }^{66}$ As a genealogist, then, my intention is not to discover some essential characteristics about the Muslim girl, but to investigate the different appearances of this girl and inquire into how she comes into being, the webs of discourses in which she is entangled, and the ways in which her constitution shifts over time. These shifts are an effect of power relations. Thus, in order to appreciate how certain subjects become intelligible and others deviant or unthinkable, we have to explore the nexus of power/ knowledge. Genealogy is also attentive to the recurrence of discursive tropes, "not in order to trace the gradual curve of their evolution, but to isolate the different scenes where they engaged in different roles." ${ }^{67}$ In the context of my book, notions of respectability sutured onto middle-class sensibilities as well as ideal religious performances are some concerns that recur but perform different functions across time and in relation to women and girls from different social classes. 
It is with these methodological lenses that I trace the subjects who become recognizable as "educated Muslim women/girls," as well as those who are marked as being outside the pale of recognition. Significantly, I argue that at any given moment in time, we find multiple articulations of what it means to be an educated woman/girl vying for dominance.

\section{Assembling an Archive}

A genealogy constitutes its own events because it is a narrative that has a political purpose. ${ }^{68}$ For each of the periods under consideration, I have assembled cultural texts (linguistic and visual) that enable me to piece together dominant visions of ideal and failed woman-/girl-subjects. These include magazine articles, government documents, speeches by politicians, didactic novels, advertisements, television shows, research reports, focus group transcripts, and marketing materials of development campaigns. Together, these texts signal some of the prominent discursive connections of their time. Many elements of these archives can be described as being part of the public culture, which Akhil Gupta defines as "a zone of cultural debate conducted through the mass media, other mechanical modes of reproduction, and the visible practices of institutions such as the state." ${ }^{69}$ Public culture is one of the most salient modalities for the discursive construction of the educated girl/woman. I will take a moment here to explain the kinds of texts I take up in each of the chapters and their affordance for my project.

In chapter 2, which focuses on the turn of twentieth century, I begin by mapping some of the ongoing debates about women's education by centering the political writings, speeches, and advice novels of prominent Muslim social reformers, who were predominantly men. These texts help to ascertain some of the prevailing anxieties and concerns, not only about women and their education, but also about the impending economic decline in the context of the expansion of the colonial state. I then draw on women's writings that appeared in periodicals, specifically Ismat, Tehzib-e-Niswan, and Khatun, and the didactic novels written by the pioneer female author/editor Muhammadi Begum, namely Sughar beti (Refined Daughter; 1905), Sharif beti (Respectable Daughter; 1908), and Hayat-e-Ashraf (The Life of Ashraf; 1899). While male social reformers' writings enjoyed healthy circulation, this was not so for women's writings, which often appeared in meagerly funded periodicals, still in their infancy during the early decades of the twentieth century. These periodicals, in fact, were not even considered worthy of digitization and archiving until very recently and, thus, have been largely neglected in the official writing of history.70 I examine these periodicals because they formed one of the discursive sites where ashraf (respectable) women engaged with each other. Their writings, thus, provide an additional layer of understanding about the project of making women/girls at the turn of the twentieth century. 
In chapter 3, while continuing to work with women's periodicals, I include additional documents such as national education policies, newspaper advertisements, political speeches, and a qualitative study conducted with girls, entitled the Educated Pakistani Girl, by Asaf Hussain in 1963. These texts illuminate ideal (gendered) citizen-subjects needed for the project of nation building, modernization, and development. When I arrive at the present moment (chapter 4), I outline the ideal girlhood established in and through transnational girls' education campaigns and complicate it by drawing on findings from focus group conversations conducted with girls, teachers, and parents in a city in South Pakistan, during the summer of 2015. I take these interviews to be performative, where my interview subjects narrate their educational trajectories and desires, and in doing so provide yet another glimpse into ideal educated girlhoods. I stay in the current moment in chapter 5 and examine two television shows aired in Pakistan in 2011 and 2012, which are based on Nazir Ahmed's Mirat-ul-uroos (The Bride's Mirror; 1869), taken up in detail in chapter 2 . These televised productions afford me the possibility of tracking how concerns around gender and education have transmuted over a century. The final chapter of the book outlines overlapping storylines that emerge across the moments and sites centered in this book.

While I engage with a broad range of texts, this book is not about them. That is, I make no effort to understand the texts' (and their authors' or narrators') "true" meaning. I am more interested in the social conditions within which the texts become possible and intelligible, what the texts do, and what they produce. This approach enables me to examine discourses about women's and girls' education across different moments, not to determine causal links or to be comprehensive but to explore their connections and ruptures with other discourses that I am concerned with, such as the discourse on sharafat (respectability), class and religious performances, and nation building. As a genealogist who has commitments to transnational feminist and postcolonial theories, I trace the ways in which calls for education are linked with other calls-for inaugurating civilization, reproducing class sensibilities, signaling respectability, boosting economic growth, enacting modernity, or curating religious identity. In the process Muslim women and girls are called on to acquire the type of education that can enable them to effectively deliver on these societal projects.

\section{Analyzing the Archive}

While political speeches and texts might seem to be a logical choice for a genealogy, in that they provide a glimpse into the then prevailing political regimes, literature seems less so given the apparently fictive nature of the enterprise. However, I am influenced by Lee Quinby, who elaborates on the value of literary works for genealogy. ${ }^{71}$ She notes that literary texts often engage with, and elaborate on, key issues of their time, and have also served as a disciplinary technology of colonization. Genealogies 
that take up literature then teach us about attitudes toward ongoing issues, as well as how literature partakes in establishing dominant regimes of truth. Indeed, poststructural scholars do not take such texts to represent essential truths-texts are not autonomous; ${ }^{72}$ rather they "tell stories,"73 and often multiple stories depending on the positionality of the reader. This view of literature is productive for me, as I examine texts written or commissioned by British colonial officers, religious ulema, modernists, and nationalists, who had different approaches to education, religion, and men's and women's roles in society. Furthermore, their differential access to resources also translated into varying abilities to produce and transmit knowledge.

Methodologically, examining these texts entails attending to the personal, social, and historical contexts within which the authors created them. ${ }^{74}$ It also entails exploring the audiences imagined by the text, and what the text does in relation to opening up and foreclosing subject positions. This method of engaging with texts by attending to the knowledge regimes within which they circulate has been described as by Wendy Hesford as "intercontextuality": "To read intercontextually is to identify in a composition or performance the internal references to other texts or rhetorical acts, to become reflexive about the social codes and habits of interpretation that shape the composition or performance's meaning and that it enacts, and to comprehend how texts are formed by the institutions and material contexts that produce and through which they circulate."75

Enacting this method entails attending not only to the internal references of the texts but also placing them in the longer histories of cultural and social articulation, exploring the assumptions and knowledges that they draw upon, and how they move about in the world. For instance, colonial officers from the Public Instruction Offices in North India often contracted Muslim writers to author books about women's education. They were also active in selecting books that aligned with their views and assigned them as official textbooks in public schools. Nazir Ahmed's advice novel, Mirat-ul-uroos is one such text that received praise and monetary prizes from M. Kempton, who was the director of public instruction of Northwestern Provinces from 1862 to 1878, and also the lieutenant governor of Northwestern Provinces. ${ }^{76}$ Such moves often antagonized the ulema, who wanted a different kind of education for women. In Bahishti zewar (Heavenly Ornaments; 1905), Ashraf Ali Thanawi (a well-known religious scholar) lists Nazir Ahmed's book as one that should be banned. The texts, then, have a life beyond themselves. They provide a glimpse into the ongoing contestations around women's and girls' education. Significantly, the autobiographical and biographical texts that I take up in this book, written predominantly by women, are particularly well positioned for this form of inquiry and analysis. As texts that sought to locate the personal within the social and political, they become generative spaces for me to examine what was experienced as a social reality, as well as to obtain insights into a new reality that the authors sought to establish through the very practice of writing. 
The texts are also useful in providing a glimpse into the making of social class. Bourdieu theorizes class not only as income levels and economic opportunities, but also as aesthetics, language, and consumption practices. ${ }^{77}$ Elsewhere, Jane Kenway and others argue that class is always in the making; ${ }^{78}$ it is articulated, disarticulated, and rearticulated through connections with race, gender, nation, and ethnicity. The task of the researcher, then, is to examine how class-based solidarities, aesthetics, preferences, rituals, and hostilities are produced. In the book, readers will observe how social class is made through women's practices, which are in turn shaped by notions of respectability. In other words, it is the respectable woman who is the vanguard and symbolic representative of her social class. However, this woman is fashioned differently as class aesthetics change over time and space. As Kenway et al. note, "to study class is to . . certainly identify longstanding practices, repeated patterns of behavior, the role of custom and convention. Importantly, it is not only about identifying such repetition but is also about identifying the effort of class invention, ingenuity and imagination." 79 The texts taken up in this book provide a peek into how women's education is expected to engender particular class sensibilities and aesthetics, while cautioning them against others. ${ }^{80}$

\section{Engaging with Women's Narratives}

There are multiple ways in which women's narratives have been taken up in genealogical projects. The first entails recuperating women's experiences and voices, and adding them to the long-standing narratives of history produced predominantly by men. This strategy sees "woman" as a stable, knowable category and views the endeavor of adding women's voices as a corrective. In doing so it produces a women's record that runs parallel to narratives of men. The second approach, however, takes gender as an analytical category and traces how gender and sexuality organize social life. ${ }^{81}$ This approach views women's voices as part of broader assemblages, linked with race, class, and religion, and providing partial perspectives. Joan Scott has named these approaches as writing "women's history" versus "gender history," respectively. ${ }^{82}$ I locate this book within the field of gender history to illuminate the operation of gender as a discourse in and through which negotiations and contestations around class, religion, and nation building take place. Even as I recover the first-person writings of Muslim women from the turn of the twentieth century and include Pakistani girls' narratives from 2015 (in chapter 4, as findings from focus group interviews), I view them as yet another kind of "text," which provide a partial glimpse into ongoing knowledge regimes. They are a part of my broader archive, although I recognize that this part has been neglected in official writings and, hence, seek consciously (and laboriously) to bring it into our conversation. As this book shows, Muslim women's writings from early- or mid-twentieth-century Pakistan do not radically depart from the ongoing rationales, concerns, and investments that were felt by men of similar social class and 
geographical locations. Indeed, women writers were embedded in their social and cultural milieu, resisting as well as acquiescing to reforms aimed at them. Their writings, then, tell stories about the dominant knowledge regimes and hint at both individual and communal interests.

A fortunate consequence of writing this genealogy is also that it disrupts present-day certainties about the silence of Indian Muslim women of the past. Such assumptions have enormous representational power in current collective imagination. Tropes of the "silent, uneducated Musalman woman who was/is married early and/or lives in polygamous households at the mercy of hypersexual Muslim men" continue to inform international discourses on girls' empowerment and education, as well as western foreign and domestic policies. Deploying women's narratives from the past interrupts these certainties by showing women to be fully human and political subjects. Furthermore, as Azra Asghar Ali notes, the lack of understanding about the voices of Indian Muslim women presents a key gap in our knowledge of how Muslim women's spaces opened up in the twentieth century. ${ }^{{ }_{3}}$ This book hopes to address that gap.

Like any study, mine too has its limitations. The focus on particular moments, decades, texts, and themes entails downplaying or ignoring others. I do not discuss events in other time periods that have had an effect on how we have come to recognize and imagine educated female subjects. This opens me up to the critique of periodization, where particular events and time periods are marked as representational in the life of a nation or community. However, since this book is a genealogy, my objective has been to make a political argument about the figure of the educated girl. I am interested in broader systems of reasoning about women and girls that entail inclusions and exclusions, and help to produce particular kinds of subjective experiences among women and girls. It is these motivations that have informed my selection of texts, periods, and events. 